\title{
Far from boring: a new Grenvillian perspective on Mesoproterozoic tectonics
}

Félix Gervais ( $\square$ felix.gervais@polymtl.ca )

Polytechnique Montreal

Alexandre Beaudry

Polytechnique Montréal

Charles Kavanagh-Lepage

Polytechnique Montréal

Abdelali Moukhsil

Direction de l'acquisition des connaissances géoscientifiques

Physical Sciences - Article

Keywords: Mesoproterozoic, Grenvillian Orogeny, tectonic quiescence

Posted Date: October 26th, 2021

DOI: https://doi.org/10.21203/rs.3.rs-847663/v1

License: (9) This work is licensed under a Creative Commons Attribution 4.0 International License. Read Full License 


\section{Abstract}

As determining when plate tectonics began on Earth is a highly debated subject, it is crucial to understand the "boring billion" (1.8 to 0.8 billion years ago), a period of tectonic quiescence inferred from proxies, such as the average chemical composition of the mineral zircon on Earth and the isotopic composition of seawater derived from marine rocks. Yet this period saw the construction of what may have been the biggest mountain belt that ever existed, the remnants of which are found in the Grenville Orogen of eastern North-America. This contribution first exposes a compilation of multidisciplinary geological datasets and new geochemical data from igneous suites emplaced during the Grenvillian Orogeny that are incompatible with the current tectonic paradigm. We then present a completely revised model for Grenvillian tectonics. In contrast with the actual Laurentian-centred paradigm, our model involves the construction of a newly revealed continent by amalgamation of volcanic arcs far away from Laurentia (the craton forming the core of actual North-America) and their collision 60 millions year later than the currently accepted timing. This new model resolves the longstanding contradiction between tectonic proxies and geological record and invalidates the view considering the Mesoproterozoic as a tectonically quiet Era.

\section{Main Text}

The Mesoproterozoic Era, more specifically 1.8-0.8 billion years (Gyr) ago is one of the most enigmatic period of time on Earth that has been referred to as "the boring billion"1. It was related to a prolonged phase of tectonic quiescence ${ }^{2-5}$ from several proxies of tectonic activities, notably: 1 ) the paucity of passive margins in the geological record $\left.{ }^{6} ; 2\right)$ a systematic decrease in normalized seawater ${ }^{87} \mathrm{Sr} /{ }^{86} \mathrm{Sr}$ ratio $^{7}$, which is a hallmark of juvenile (igneous rocks produced directly by mantle melting) rock erosion. Detrital zircon (of sedimentary origin) of this Era collected on all continents on Earth further show: 3) a systematic decrease in Eu anomaly inferred to indicate a decrease of the average crustal thickness ${ }^{2}$; 4) a stable high value in $\varepsilon \mathrm{Hf}$ indicating a high average mantle input in igneous activity; as well as 5 ) a peak in abundance ${ }^{9,10}$ and 6 ) a peak in $\delta 0^{18} 1.1 \mathrm{Gyr}^{-a g o}{ }^{11}$. Although, these last two proxies have been related to collisional orogenesis ${ }^{10}$, there is compelling evidence that zircon abundance correlates with subduction flux ${ }^{12}$, and high $\delta 0^{18}$ in zircon is usually interpreted as evidence for sediments incorporated into subduction zones ${ }^{13}$. Accepting the view that plate tectonics was active during the Mesoproterozoic ${ }^{14-16}$, these characteristics suggest that Earth was dominated by volcanic arcs formed above subducting oceanic crust.

This setting derived from proxies of tectonic activity contrast greatly with the geological record. Indeed, the Mesoproterozoic saw the formation of a mountain belt, now exposed as the Grenville Province (Fig. 1), covering more than $25 \%$ of the globe with and extensive paleo-fluvial system shedding sediments throughout Laurentia ${ }^{17}$. The current paradigm postulates that it formed through a complex evolution, first involving the growth of an extensive continental arc, very similar to the Andes, by NW-directed (present coordinates) subduction underneath Laurentia between 1.8 and 1.3 Gyr-ago, followed by episodes of 
continental back-arc opening and closing with localized arc accretions ${ }^{18,19}$. This evolution would have culminated in a collision between Laurentia and another continent, inferred to have been Amazonia $\left(\right.$ e.g. $\left.{ }^{20}\right)$, during the Grenvillian Orogeny, that would have started at 1.1 Gyr-ago.

This extensive mountain belt, referred to as the orogenic climax of Earth by some authors ${ }^{21}$, should have strongly influenced the above-mentioned proxies. The crust would have been thick for most of this period, which should have resulted in a high Eu anomaly, its weathering should have increase ${ }^{87} \mathrm{Sr} /{ }^{86} \mathrm{Sr}^{7}$ ratio and decrease the $\varepsilon \mathrm{Hf}$ in zircon. Finally, subduction flux would have ceased at $1.1 \mathrm{Gyr}$-ago, not peaked as suggested by zircon abundance and $\delta \mathrm{O}^{18}$. All these predictions are the opposite of the measured values.

Adding complexity to this paradox is the tectonic setting within the interior of Laurentia. Located in the footwall of the current Grenville Front, the Midcontinent rift (MCR on Fig. 1) and the Southwestern Large Igneous Province ${ }^{23}$ were major mafic magmatic events that required significant extension of the crust from 1.15 to 1.08 Gyr-ago ${ }^{24}$. Synchronously, major sedimentary basins were created by rifting ${ }^{25}$ more than $3000 \mathrm{~km}$ towards the hinterland (Fig. 1). Furthermore, recent field-based and geochemical studies of sedimentary rocks in the MCR documented wave-influenced structures and marine sedimentation ${ }^{26,27}$. These results have major implications for Grenvillian tectonism because it suggests that the MCR formed an embayment open to the ocean and that the entire Laurentian continent was under extensional stress at the same time as the Grenvillian continental collision was supposedly at its climax.

In light of all these contradictions, we consider that a critical evaluation of the geological record is required to investigate whether the data could be compatible with another tectonic model than the currently accepted Grenvilian paradigm.

\section{Geological setting}

The Grenville Province is subdivided into two belts separated by the Allochthon Boundary Thrust (ABT). In the footwall of the ABT, the Parautochtonous Belt consists of Laurentian basement rocks overlain by a Paleoproterozoic passive margin sedimentary sequence deposited 1.9 Gyr-ago ${ }^{19}$. In the hanging wall of the ABT, the Allochthonous Belt consists of (all interpretations of tectonic settings according to the current paradigm ${ }^{19}$ ): i) juvenile arc rocks formed 1.8-1.6 Gyr-ago accreted to Laurentia shortly after their formation; ii) extensive granitoids emplaced in a continental-arc setting 1.5 to 1.3 Gyr-ago; iii) sediments and igneous rocks deposited/emplaced in a continental back arc setting 1.5 and 1.3-1.2 Gyr-ago; iv) two volcanic arcs accreted to the continental arc; $v$ ) anorthosite-mangerite-charnockite-granite massifs mainly emplaced 1.15 Gyr-ago. The Grenvillian Orogeny itself is subdivided into two main orogenic phases, an early Ottawan and a late Rigolet phase ${ }^{19,20}$. The former phase occurred between 1.09 and-1.02 Gyr-ago, is only recorded in the Allochthonous Belt (Fig. 2) and is considered as a Himalayan-style continentcontinent collision, characterized by the flow of hot ductile crust below an orogenic plateau ${ }^{28}$. Renewed convergence during the Rigolet phase, from 1.01 to $0.98 \mathrm{Gyr}^{-a g o}{ }^{22}$, propagated deformation towards the 
foreland and both the reworked Laurentian basement rocks and its sedimentary cover underwent partial melting at high pressure ${ }^{29}$.

The period between the continental arc and collisional phases is contentious. There is evidence for highgrade metamorphism and associated deformation at different times and places between 1.3 and 1.1 Gyrago ${ }^{19}$ with the most spatially extensive phase occurring during the "Shawinigan Orogeny" between 1.17 and 1.15 Gyr-ago. Models of continental back-arc closure ${ }^{30}$, volcanic arc accretion ${ }^{31}$ and beginning of continental collision ${ }^{18}$ have been proposed for this period and are contradictory with each others.

\section{8-1.2 Gyr-ago: comparison with the Andes}

As the current tectonic paradigm for the first phase of construction of the Grenville Province (1.8-1.2 Gyrago) is very similar to that of the Andes ${ }^{18}$, both orogens should share key characteristics. Rivers and Corrigan ${ }^{18}$ presented several similarities between the two including protracted magmatism $(>300$ Myr for the Grenville) and several phases of back-arc sedimentation associated with bimodal volcanism, but other characteristics diverge. First, basement inliers crop out along the entire length of the Andes ${ }^{32}$, whereas there are no Laurentian basement rocks in the Allochtonous Belt of the Grenville Province. Secondly, according to the Andean model, there should have been igneous rocks emplaced in the plate overlying the subduction zone, thus in the overlying Laurentian rocks, however there are no such rocks in the Parautochtonous Belt (Fig. 2).

Andean volcanic rocks present ubiquitous evidence for crustal contamination of subduction-derived magma 33,34 . To test whether igneous rocks of the Grenville Province also present evidence for contamination, we extracted geochemical data for similar mafic rocks from the two orogens. On the Pearce diagram (Fig. 3A), Andean rocks define a field above the mantle array towards high Th values indicating crustal contamination, whereas Grenvillian rocks plots in a field centered on the array indicating igneous rocks extracted directly from the mantle ${ }^{35}$.

Another way to determine the extent of crustal contamination is to examine the difference between $\mathrm{Nd}$ model ages, indicating the timing of extraction from the depleted mantle, and U-Pb ages for igneous suites, indicating the timing of their emplacement. In the Central Andes, there is a difference of at least $0.8 \mathrm{Gyr}$ between $\mathrm{Nd}$-model ages and emplacement (U-Pb) ages of Neogene-Quaternary volcanics ${ }^{33,34}$, whereas it is less than $0.22 \mathrm{Gyr}$ in the Grenville Province (Fig. 3B). This is best explained by extensive contamination of recent mafic magma by crustal rocks 1 Gyr older in the Andes, but minimal contamination of Grenvillian magma by a basement that should have been 1.7 Gyr older (Archean Laurentian basement).

\section{2-0.95 Gyr-ago: testing the Grenville Orogen paradigm}

Other geological features associated with the Grenvillian Orogeny do not fit with the current tectonic paradigm. The current model involves thrusting of the Allochthonous Belt over the Laurentian basement 
along the ABT 1.1-1.05 Gyr-ago. There should thus be a tectono-metamorphic imprint in the underlying Parautochthonous Belt, but temporal constraints for deformation and metamorphism document deformation at amphibolite to granulite grade only 40-60 Myr later in this belt (Fig. 2).

Tectonic discrimination diagrams based on immobile trace elements composition of mafic and felsic igneous suites emplaced before and during the accepted timing of orogeny also challenge the current model. Mafic suites with U-Pb emplacement ages between 1.15 and 1.09, 1.09-1.03 and <1.03 Gyr-ago plot in the subduction-related, Andean and subduction-related fields, respectively (Fig. 3C). Similarly, felsic suites dated between 1.15-1.03 and <1.03 Gyr-ago plot in the arc and slab failure to A-type fields, respectively (Fig. 3D). Combined, these datasets indicate a volcanic arc setting with minimal crustal contamination between 1.15 and 1.09 Gyr-ago that evolved into an Andean setting between 1.09 and 1.03 Gyr-ago, at which point the slab broke and lead to the intrusion of magma derived from mantle melting. This geochemically-derived tectonic evolution is, therefore, strikingly different than an Andean setting until continental collision between 1.09 and 0.95 Gyr-ago.

\section{A new tectonic model}

We propose a radically new model for the tectonic evolution of the Grenville Province that reconciles all the issues raised above. After the passive margin phase $1.9 \mathrm{Gyr}$-ago, intra-oceanic subduction developed thousands of kilometers away from Laurentia and formed several volcanic arcs accompanied by opening and closing of back-arc basins between 1.7 and $1.2 \mathrm{Gyr}$-ago (Fig. 4A). The final amalgamation of all arcs occurred during the Shawinigan Orogeny between 1.17 and 1.15 Gyr-ago (Fig. 4B) to form a microcontinent, here named Shawiniga. Andean-style tectonism then started with southward subduction of oceanic crust beneath Shawiniga. We follow Swanson-Hysell et al. ${ }^{24}$ who proposed a model of slab avalanche dragging Laurentia rapidly southward to explain the fast plate motion derived from paleomagnetic data from the MCR for the period between 1.1 and 1.08 Gyr-ago (Fig. 4C). In accordance with numerical model of slab avalanche predicting shortening in the upper plate ${ }^{38}$, we further argue that fast subduction underneath Shawiniga lead to significant crustal shortening and thickening (Fig. 4C). Because it is separate from the later continental collision phase, we propose the name Ottawan Orogeny for this slab-avalanche phase, which was previously considered as the initial phase of the Grenvillian Orogeny.

Collision between Laurentia and Shawiniga occurred during what was previously considered as the second phase of the Grenvillian Orogeny (the Rigolet). We estimate the timing of this collision at ca. 1.03 Gyr-ago based on the drastic change of chemical composition for mafic and felsic igneous rocks (Fig. 2, $3 C \& D)$, and the timing of metamorphism in both the Parautochtonous and Allochtonous belts suggest it lasted until ca. 0.96 Gyr-ago (Fig. 2).

\section{Discussion}


The new Grenvillian tectonic model presented herein (Fig. 4) is compatible with more geological data than the current tectonic paradigm. All the geological features of the Allochtonous Belt described in the geological setting and comparison with the Andes sections could have formed in oceanic arcs rather than continental arcs (Fig. 4A). The age pattern of detrital zircons from ca. 1.5-1.3 Ga Grenvillian basins in the Allochthonous Belt, including 2.7 and 1.8 Ga peaks, was used to imply a Laurentian affinity ${ }^{39}$, however it was demonstrated that such peaks are common to all continents and therefore are not diagnostic 9 . Amalgamation of several arcs (Fig. 4B) is also compatible with the spatially and temporally variable events of metamorphism and deformation documented between 1.3 and $1.1 \mathrm{Gyr}$-ago ${ }^{19}$. Most importantly, the new model reconciles the absence of Laurentia in both the rock record and geochemical characteristics in the Allochthonous Belt (Fig. 3A\&B), as well as the absence of Mesoproterozoic subduction-related intrusions in the Parautochthonous Belt (Fig. 2). Furthermore, a collision between the newly-named continent Shawiniga (comprising rocks of the Allochthonous Belt) and Laurentia 1.03 Gyrago provides an elegant explanation for the lack metamorphic and deformation imprints in the Parautochtonous Belt 1.1-1.05 Gyr-ago, but reworking of Allochthonous metamorphic rocks between 1.03 and 0.95 Gyr-ago (Fig. 2). Finally, tectonic discrimination diagrams for felsic and igneous rocks emplaced between 1.15 and 0.95 Gyr-ago present a pattern that strongly supports the model presented herein (Fig. $3 C \& D)$.

In this new model, Laurentia was not involved in Grenvillian orogenesis until its latest stage. Laurentia was thus a passive margin throughout most of the Mesoproterozoic, with access to sea water such as documented in sedimentary rocks of the $\mathrm{MCR}^{26,27}$. The extremely fast motion of Laurentia between 1.1 and 1.08 Gyr-ago dragged by slab avalanche, would likely have put the entire continent under extension and generated all the major sedimentary basins and large igneous province such as the MCR that formed during this period ${ }^{24,25}$.

Moreover, our model better reconciles proxies of tectonic activities used to infer tectonic quiescence during the so-called "boring billion". First, one of the main arguments for tectonic quiescence, the paucity of passive margins, is invalidated by our model postulating that the entire SE margin of Laurentia would have been a passive margin from 1.9 to 1.03 Gyr-ago (Fig. 4A-C). Most of the sediments deposited during this phase are difficult to recognize because they were deeply buried, metamorphosed and deformed when Laurentia was underthrust by Shawiniga. Second, the consumption of several 1000's of km of ocean crust during the slab-avalanche event proposed in our model is a special event that would likely have resulted in a peak in subduction proxies ca. 1.1. Gyr-ago, such as the peak in zircon abundance and their $\delta \mathrm{O}^{18}$ values observed in worldwide detrital zircon $9,11,40$. Similarly, by removing the protracted Andean phase and reducing the duration of collisional orogenesis, the proposed Grenvillian model is more compatible with the low crustal thickness inferred from Eu anomaly in zircon². Finally, the recorded decreasing ${ }^{87} \mathrm{Sr} /{ }^{86} \mathrm{Sr}^{7}$ ratio in seawater and high $\varepsilon \mathrm{Hf}$ in zircon recorded for the Mesoproterozoic ${ }^{7,8,16}$ are the expected proxies for our model, dominated by oceanic arcs until 1.1 Gyr-ago (Fig. 4A-C), that would 
have shed large volume of juvenile sediments in the oceans. Inasmuch as the southward motion of Laurentia ${ }^{24}$ suggests that these arcs were at equatorial latitudes, this setting should have led to a cold Earth ${ }^{41}$ prior to the assembly of the supercontinent Rodinia.

In conclusion, recasting Grenvillian tectonics into a model involving the formation of a microcontinent comprising several oceanic arcs that would have collided with Laurentia $60 \mathrm{Myr}$ after the currently accepted timing of collision, allows to integrate a larger multidisciplinary geological dataset and tectonic proxies into an internally consistent tectonic model. In contrast with recently proposed views ${ }^{2-5}$, it demonstrates that the Mesoproterozoic was far from being boring ${ }^{15,21,42}$ and tectonically active. We anticipate that this new perspective on Grenvillian tectonism will unlock new research on slab-avalanche influence on mountain-building processes, paleogeographic reconstruction, Artic basins formation, evolution of plate tectonics through time, as well as quantifying the initial conditions for modeling climate change associated with the transformation of Earth into a Snowball ${ }^{43}$.

\section{Methods}

For figure $3 \mathrm{~A}$ and $3 \mathrm{C}$, geochemical data for basaltic rocks of intrusive suites from the Andes and from the Grenville allochthonous belt were compiled. The Andean arc geochemical data was taken from Georock database (http://georoc.mpch-mainz.gwdg.de). The data from the Grenville province were taken from published data from the literature and unpublished data from Quebec's geoscientific database SIGEOM. Dykes and intrusions were taken out from this dataset as they are likely post-orogenic late intrusions. Filters were applied to focus on basaltic rocks according to Pearce, 1996: Si <55wt\%; Al203>20wt\%; Sc > $50 \mathrm{ppm}$ and $\mathrm{Ni}>200 \mathrm{ppm}$. For figure 3D, granitic rocks data were compiled from published data. A silica filter was applied (Si 55 to $70 \mathrm{wt} \%$ ) for granitic rocks. Diagrams were made using GCDkit software. For figure 3B, depleted mantle model ages (TDM) were compiled (Dickin et al., 2010; Dickin, 2000; Dickin and McNutt, 2007; Dickin et al., 2016) and overlain on a geological map from the Quebec's geoscientific database system SIGEOM with QGIS. All data points falling within an igneous suite of known U-Pb age on the time-slice geological maps from https://gq.mines.gouv.qc.ca/lexique-stratigraphique/province-degrenville_en/ were retained and the difference between U-Pb and TDM ages were used to create the boxplot shown on figure 3B.

\section{Declarations}

\section{Author Contributions}

F.G. Wrote most of the main text, drew fig.1, 3B and 4. A.B. compiled igneous data for fig. 2 and 3, wrote the captions of fig.3, drew fig. 3A, B, D and contributed to drawing fig.1. C.K-L. Compiled metamorphic data for fig.2 and contributed to drawing fig. 2. A.M. collected and compiled relevant geochemical data for fig. 2 and 3 (see supp. file) and revised the manuscript.

Supplementary Information is available for this paper. 


\section{Bibliography}

1. Holland, H. D. The oxygenation of the atmosphere and oceans. Philos. Trans. R. Soc. B Biol. Sci. 361, 903-915 (2006).

2. Tang, M., Chu, X., Hao, J. \& Shen, B. Orogenic quiescence in Earth's middle age. Science (80-. ). 371, 728-731 (2021).

3. Stern, R. J. The mesoproterozoic single-lid tectonic episode: Prelude to modern plate tectonics. GSA Today 30, 4-10 (2020).

4. Sobolev, S. V. \& Brown, M. Surface erosion events controlled the evolution of plate tectonics on Earth. Nature 570, 52-57 (2019).

5. Cawood, P. A. \& Hawkesworth, C. J. Earth's middle age. Geology 42, 503-506 (2014).

6. Bradley, D. C. Passive margins through earth history. Earth-Science Rev. 91, 1-26 (2008).

7. Shields, G. A. A normalised seawater strontium isotope curve: possible implications for Neoproterozoic-Cambrian weathering rates and the further oxygenation of the Earth. eEarth 2, 35-42 (2007).

8. Roberts, N. M. W. Increased loss of continental crust during supercontinent amalgamation. Gondwana Res. 21, 994-1000 (2012).

9. Voice, P. J., Kowalewski, M. \& Eriksson, K. A. Quantifying the timing and rate of crustal evolution: Global compilation of radiometrically dated detrital zircon grains. J. Geol. 119, 109-126 (2011).

10. Spencer, C. J., Roberts, N. M. W. \& Santosh, M. Earth-Science Reviews Growth , destruction , and preservation of Earth 's continental crust. 172, 87-106 (2017).

11. Spencer, C. J. \& Kirkland, C. L. Visualizing the sedimentary response through the orogenic cycle: A multidimensional scaling approach. Lithosphere 8, 29-37 (2016).

12. Domeier, M., Magni, V., Hounslow, M. W. \& Torsvik, T. H. Episodic zircon age spectra mimic fluctuations in subduction. 1-9 (2018) doi:10.1038/s41598-018-35040-z.

13. Valley, J. W. et al. 4.4 billion years of crustal maturation: Oxygen isotope ratios of magmatic zircon. Contrib. to Mineral. Petrol. 150, 561-580 (2005).

14. Roberts, N. M. W. Geoscience Frontiers The boring billion? e Lid tectonics, continental growth and environmental change associated with the Columbia supercontinent. Geosci. Front. 4, 681-691 (2013).

15. Spencer, C. J., Mitchell, R. N. \& Brown, M. Enigmatic Mid-Proterozoic orogens: Hot, thin, and low. Geophys. Res. Lett. (2021) doi:10.1029/2021gl093312. 
16. Condie, K. C. Revisiting the Mesoproterozoic. Gondwana Res. 1-9 (2020) doi:10.1016/j.gr.2020.08.001.

17. Rainbird, R., Cawood, P. \& Gehrels, G. The Great Grenvillian Sedimentation Episode: Record of Supercontinent Rodinia's assembly. in Tectonics of Sedimentary Basins 583-601 (John Wiley \& Sons, Ltd, 2012). doi:10.1002/9781444347166.ch29.

18. Rivers, T. \& Corrigan, D. Convergent margin on southeastern Laurentia during the Mesoproterozoic: Tectonic implications. Can. J. Earth Sci. 37, 359-383 (2000).

19. Rivers, T. et al. Chapter 3: The Grenville. Orogen - A post-LITHOPROBE perspective. Geol. Assoc. Canada, Spec. Pap. 49 97-236 (2012).

20. Hynes, A. \& Rivers, T. Protracted continental collision - evidence from the Grenville Orogen. Can. J. Earth Sci. 47, 591-620 (2010).

21. Van Kranendonk, M. J. \& Kirkland, C. L. Orogenic climax of Earth: The 1.2-1.1 Ga Grenvillian superevent. Geology 41, 735-738 (2013).

22. Rivers, T. The Grenville Province as a large hot long-duration collisional orogen - Insights from the spatial and thermal evolution of its orogenic fronts. Geol. Soc. Spec. Publ. 327, 405-444 (2009).

23. Bright, R. M., Amato, J. M., Denyszyn, S. W. \& Ernst, R. E. U-Pb geochronology of 1.1 Ga diabase in the southwestern United States: Testing models for the origin of a post-Grenville large igneous province. Lithosphere 6, 135-156 (2014).

24. Swanson-Hysell, N. L., Ramezani, J., Fairchild, L. M. \& Rose, I. R. Failed rifting and fast drifting: Midcontinent Rift development, Laurentia's rapid motion and the driver of Grenvillian orogenesis. Bull. Geol. Soc. Am. 131, 913-940 (2019).

25. Greenman, J. W., Rooney, A. D., Patzke, M., lelpi, A. \& Halverson, G. P. Re-Os geochronology highlights widespread latest Mesoproterozoic (ca. 1090-1050 Ma) cratonic basin development on northern Laurentia. Geology XX, 1-5 (2021).

26. Jones, S. M. et al. A marine origin for the late Mesoproterozoic Copper Harbor and Nonesuch Formations of the Midcontinent Rift of Laurentia. Precambrian Res. 336, 105510 (2020).

27. Stüeken, E. E. et al. Geochemical fingerprints of seawater in the Late Mesoproterozoic Midcontinent Rift, North America: Life at the marine-land divide. Chem. Geol. 553, 119812 (2020).

28. Rivers, T. Assembly and preservation of lower, mid, and upper orogenic crust in the Grenville Province-Implications for the evolution of large hot long-duration orogens. Precambrian Res. 167, 237259 (2008). 
29. Jannin, S., Gervais, F., Moukhsil, A., Augland, L. E. \& Crowley, J. L. Déformations tardi-grenvilliennes dans la ceinture parautochtone (province de grenville centrale): Contraintes géochronologiques par couplage de méthodes U-Pb de haute résolution spatiale et de haute précision. Can. J. Earth Sci. 55, 406435 (2018).

30. Dickin, A., Hynes, E., Strong, J. \& Wisborg, M. Testing a back-Arc 'aulacogen' model for the central metasedimentary belt of the grenville province. Geol. Mag. 153, 681-695 (2016).

31. Carr, S. D., Easton, R. M., Jamieson, R. A. \& Culshaw, N. G. Geologic transect across the Grenville orogen of Ontario and New York. Can. J. Earth Sci. 37, 193-216 (2000).

32. Ramos, V. A. The Grenville-age basement of the Andes. J. South Am. Earth Sci. 29, 77-91 (2010).

33. Espanon, V. R., Chivas, A. R., Kinsley, L. P. J. \& Dosseto, A. Geochemical variations in the Quaternary Andean back-arc volcanism, southern Mendoza, Argentina. Lithos 208, 251-264 (2014).

34. Franz, G. et al. Crustal Evolution at the Central Andean Continental Margin: a Geochemical Record of Crustal Growth, Recycling and Destruction. in The Andes: Active Subduction Orogeny (eds. Oncken, 0. et al.) 45-64 (Springer Berlin Heidelberg, 2006). doi:10.1007/978-3-540-48684-8_3.

35. Pearce, J. A. Geochemical fingerprinting of oceanic basalts with applications to ophiolite classification and the search for Archean oceanic crust. Lithos 100, 14-48 (2008).

36. Dilek, Y. \& Furnes, H. Ophiolite genesis and global tectonics: Geochemical and tectonic fingerprinting of ancient oceanic lithosphere. Bull. Geol. Soc. Am. 123, 387-411 (2011).

37. Whalen, J. B. \& Hildebrand, R. S. Trace element discrimination of arc, slab failure, and A-type granitic rocks. Lithos 348-349, (2019).

38. Yang, T., Gurnis, M. \& Zahirovic, S. Slab avalanche-induced tectonics in self-consistent dynamic models. Tectonophysics 746, 251-265 (2018).

39. Groulier, P. A., Indares, A., Dunning, G. \& Moukhsil, A. Andean style 1.50-1.35 Ga arc dynamics in the Southeastern Laurentian margin: The rifting and reassembly of Quebecia. Terra Nov. 1-8 (2020) doi:10.1111/ter.12482.

40. Spencer, C. J. et al. Proterozoic onset of crustal reworking and collisional tectonics: Reappraisal of the zircon oxygen isotope record. 451-454 (2014) doi:10.1130/G35363.1.

41. Macdonald, F. A., Swanson-hysell, N. L., Park, Y., Lisiecki, L. \& Jagoutz, O. set Earth 's climate state. Science (80-. ). 184, 181-184 (2019).

42. Roberts, N. M. W. The boring billion? - Lid tectonics, continental growth and environmental change associated with the Columbia supercontinent. Geosci. Front. 4, 681-691 (2013). 
43. Ramstein, G. et al. Some Illustrations of Large Tectonically Driven Climate Changes in Earth History. Tectonics 38, 4454-4464 (2019).

\section{Figures}

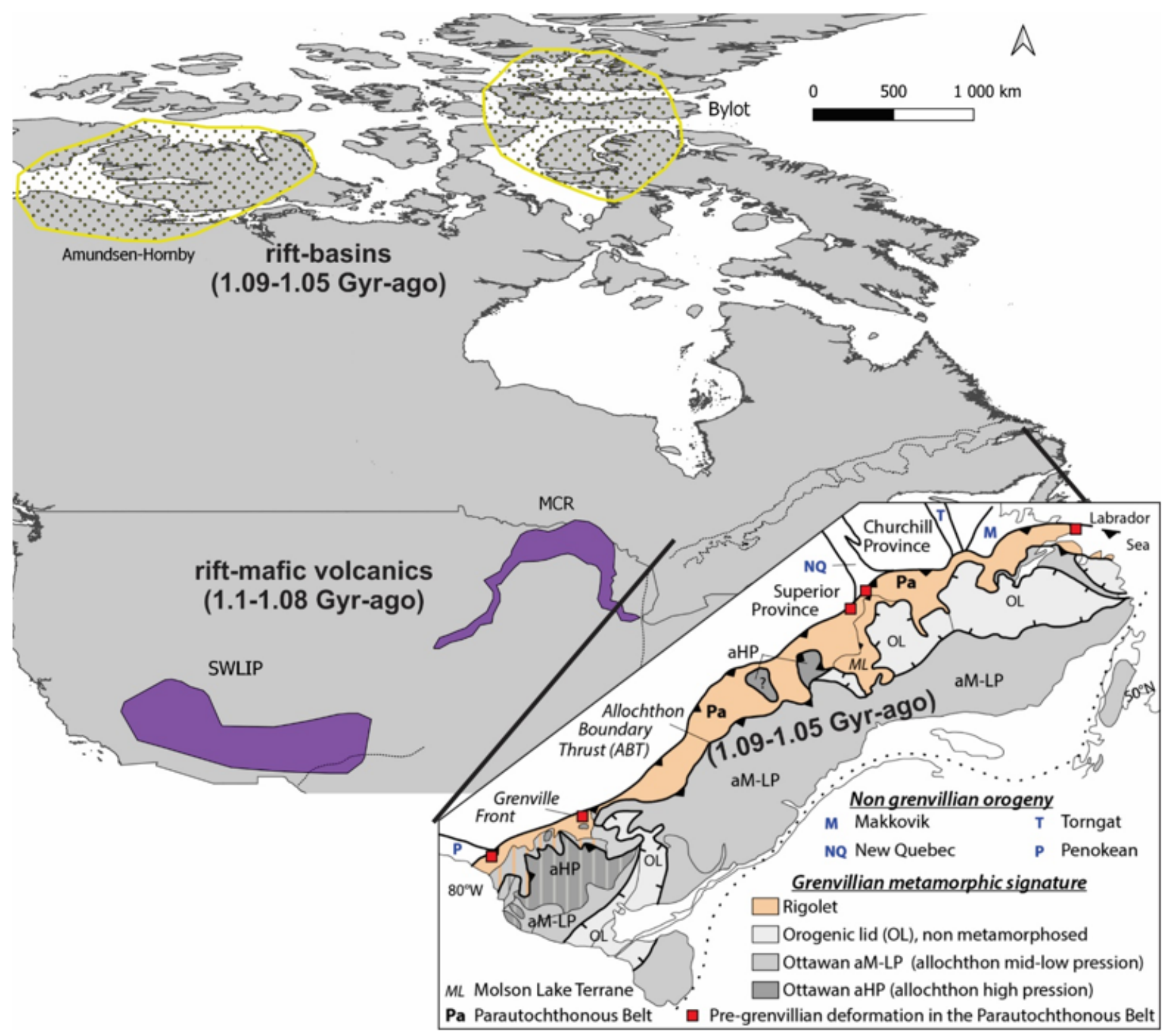

Figure 1

Geological setting of the Grenville Province in Laurentia. Present-day North America, the core of which formed the craton Laurentia during the Mesoproterozoic, showing the location of sedimentary basins and large igneous provinces that produced voluminous mafic volcanism synchronously with the Ottawan 
phase (1.09-1.05 Gyr-ago) of the Grenvillian Orogeny. Inset shows a tectonometamorphic map of the Grenville Province22. MCR = Midcontinent Rift; SWILP Southwestern Large Igneous Province23.

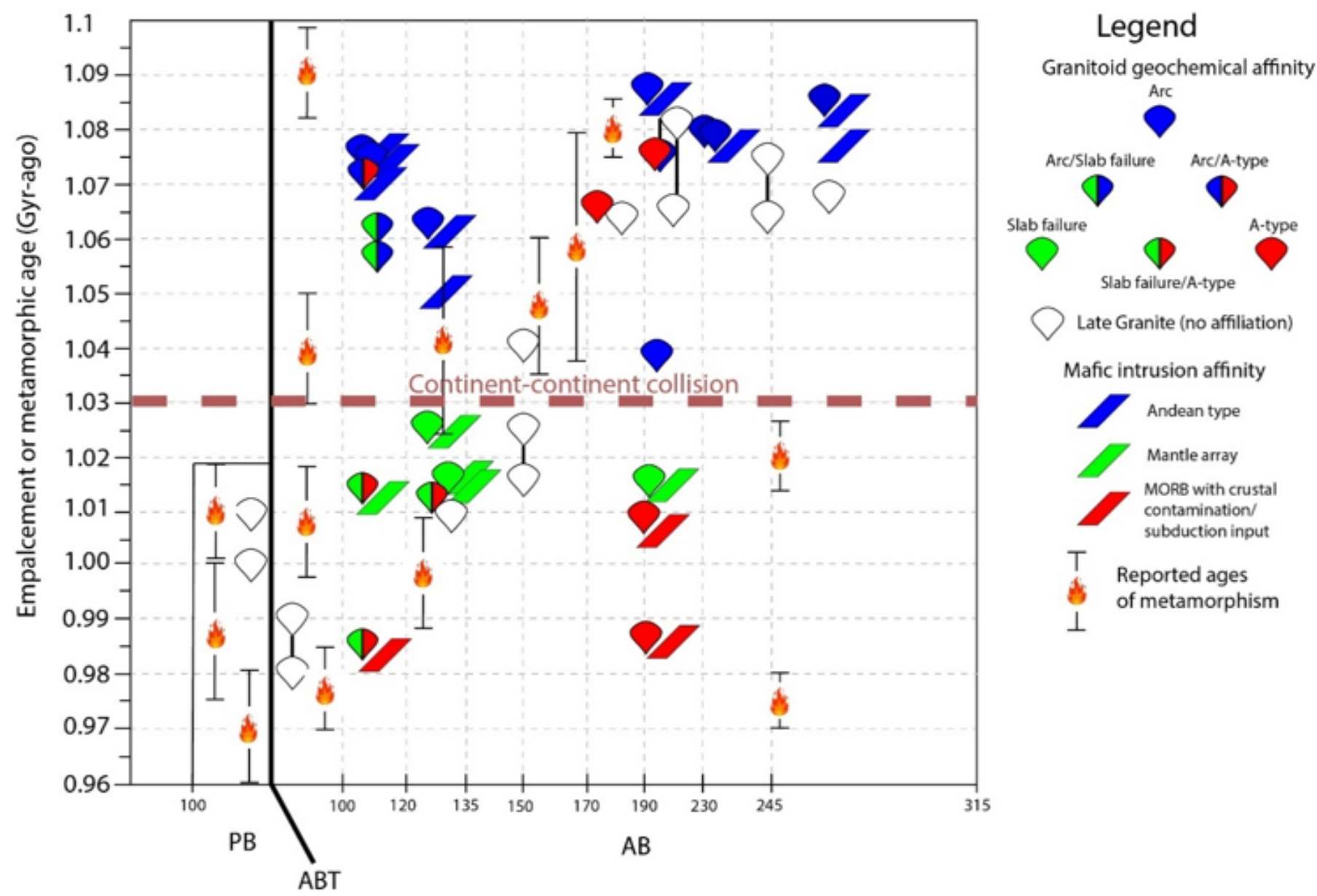

Distance from ABT $(\mathrm{km})$

\section{Figure 2}

Orogen-perpendicular 'geochronogram' through the Grenville Province. Ages of granitoid and mafic suites as well as Grenvillian metamorphic ages were compiled from the literature and projected onto a NW-SE plan orthogonal to the average strike of the $A B T$, the main tectonic discontinuity of the orogen, and positioned according to their orthogonal distance to the ABT. The affinity of granitoid and mafic rocks were determined from the geochemical tectonic-discrimination diagrams presented on figures $3 \mathrm{C}$ and $3 \mathrm{D}$ (colour code is the same on both figures). Notice the change in geochemical affinities for both types of intrusions 1.03 Gyr-ago. Also notice the absence of metamorphic ages older than $1.01 \mathrm{Gyr}$-ago in the Parautochtonous Belt (PB), but the presence of metamorphic ages of all ages within the Allochtonous Belt (AB). See text for details and interpretations. 

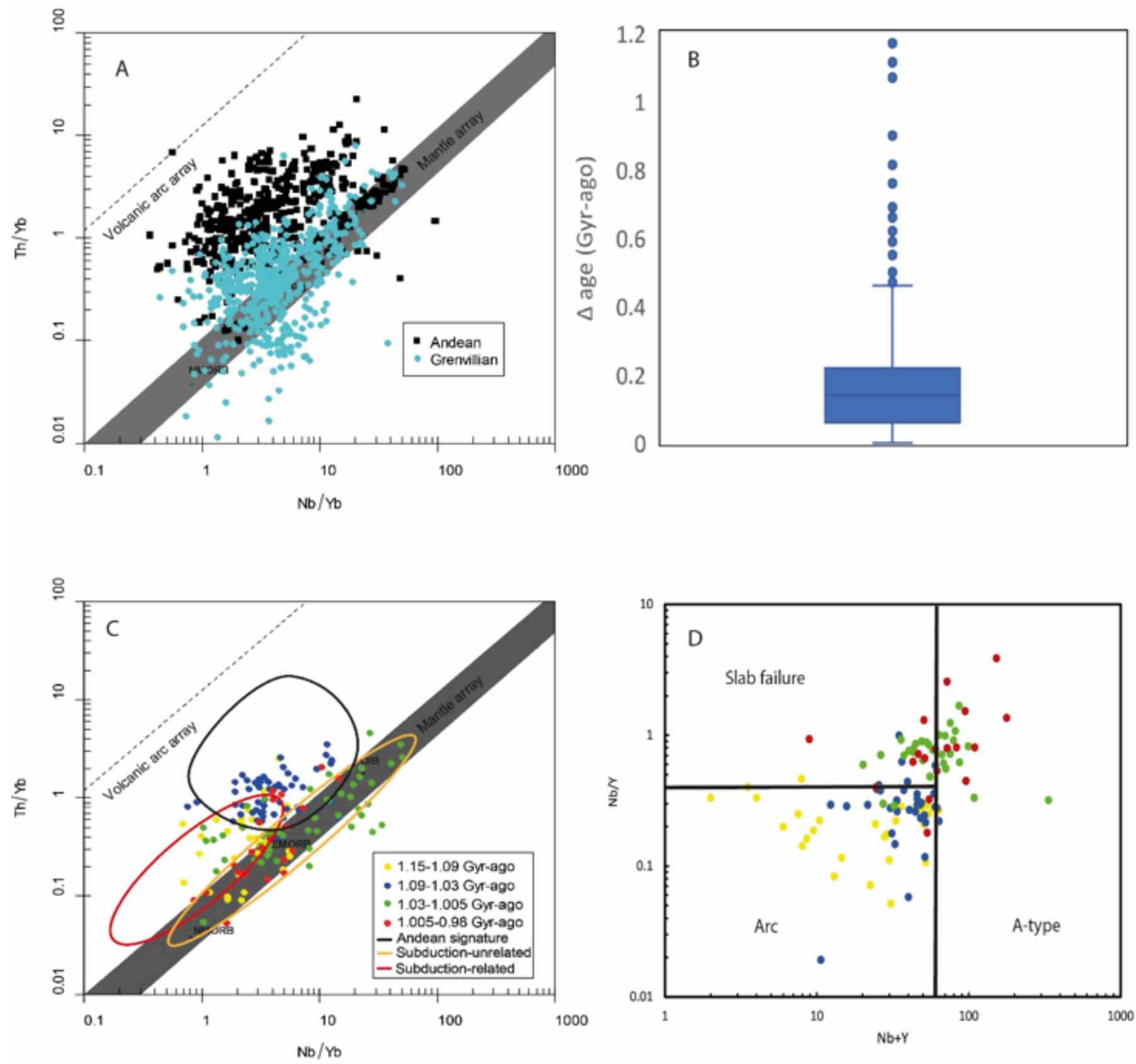

Figure 3

Geochemical tectonic discrimination plots. A) Nb/Yb - Th/Yb plot for basaltic rocks35 from the Andes and mafic rocks of the Allochthonous Belt from the Grenville. B) Boxplot of the difference between depleted-mantle $\mathrm{Nd}$ model age and U-Pb ages for igneous suites of the Grenville Province (469 data points; outlier points are $>1.5 \mathrm{x}$ times the interquartile range above the upper quartile). C) $\mathrm{Nb} / \mathrm{Yb}-\mathrm{Th} / \mathrm{Yb}$ plot35 for mafic rock suites of known U-Pb ages from the Grenville Province emplaced between 1150 and $980 \mathrm{Ma}$. The Andean-signature field is that from Fig. 3A and the subduction-unrelated and subductionrelated fields are from36. $\mathrm{D}) \mathrm{Nb}+\mathrm{Y}-\mathrm{Nb} / \mathrm{Y}$ plot37 for granitoïd rock suites of known U-Pb ages from the Grenville Province emplaced between 1150 and $980 \mathrm{Ma}$. Legend for symbols is the same as for Fig. 3C. 
A) 1.7-1.2 Gyr-ago

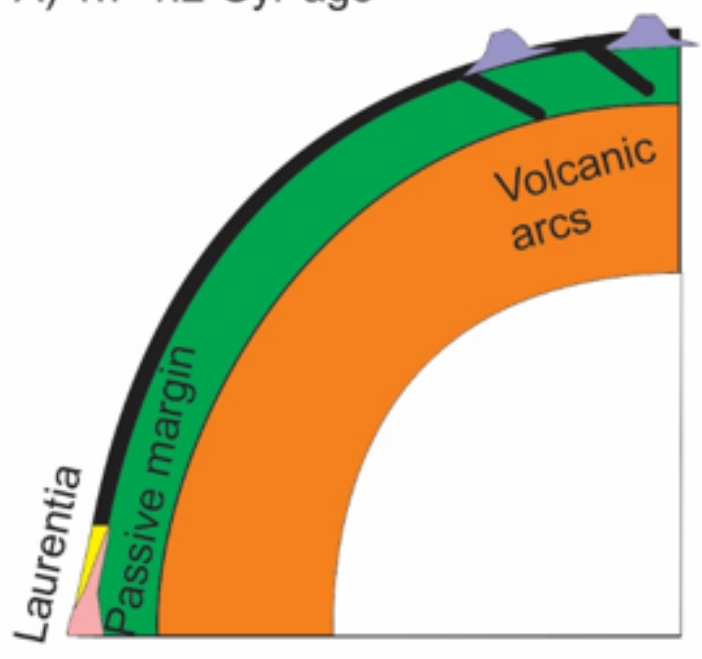

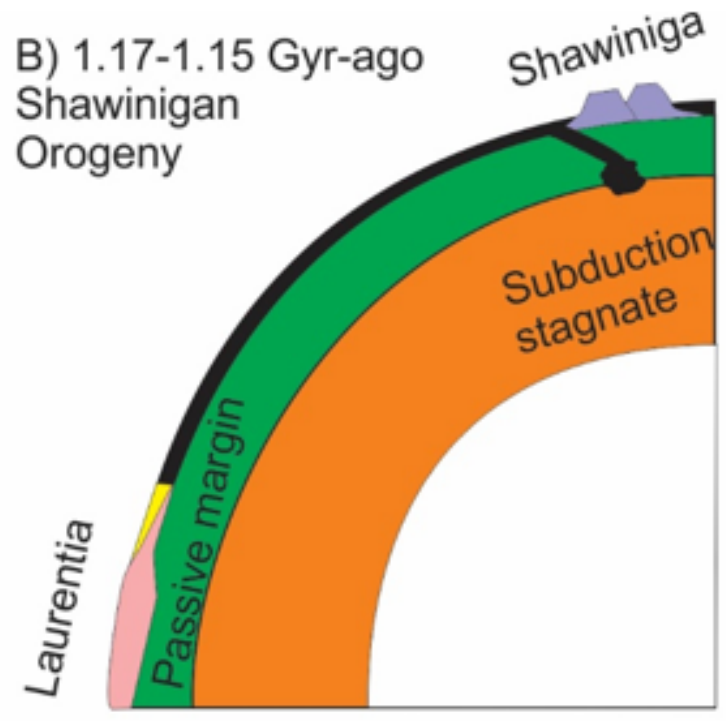
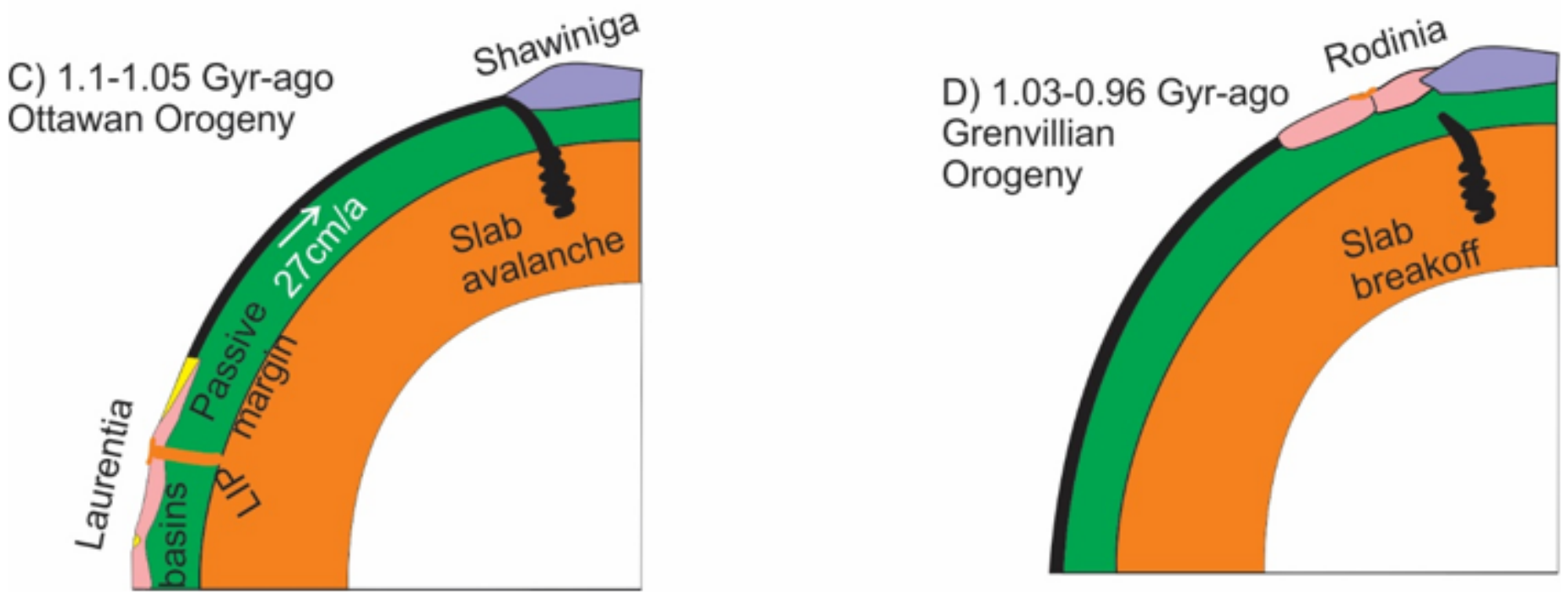

\section{Figure 4}

Summary diagram of our proposed tectonic model. A) SE margin of Laurentia in a passive margin setting and intra-oceanic subduction and magmatism leading to arc formation, back-arc opening and closing between 1.7-1.2 Gyr-ago. B) The Shawinigan orogeny led to the final amalgamation of the arcs formed in step A. This formed the continent Shawiniga comprising rocks of the Allochtonous Belt in the Grenville Province. C) Slab-avalanche stage. Subducted oceanic crust that had stagnated at the ca. $660 \mathrm{~km}$ mantle phase-boundary start foundering into the lower mantle, rapidly dragging Laurentia and leading to riftbasins formation and LIP volcanism. D) Continent-continent collision between Laurentia and Shawiniga (PB and $\mathrm{AB}$ ) occurred 1.03 Gyr-ago and continued until ca. 0.96 Gyr-ago.

\section{Supplementary Files}


This is a list of supplementary files associated with this preprint. Click to download.

- GervaisetalNatureSuppfiles.docx 